\title{
EFFECT OF Coturnix japonica (QUAIL) EGG ON SERUM GLUCOSE, B-VITAMINS AND MINERAL ELEMENTS IN ALLOXAN INDUCED DIABETIC RATS
}

${ }^{1}$ Department ${ }^{1}$ Ibrahim J, ${ }^{2}$ Lawal M, ${ }^{2}$ Isa SA, ${ }^{3}$ Abubakar A, ${ }^{4}$ Ibrahim KG ${ }^{2}$ Department of Biochemistry, ${ }^{3}$ Department of Animal Science, ${ }^{4}$ Department of Physiology, Usmanu Danfodiyo University, Sokoto

\section{Correspondence:} Dr. Ibrahim J

Department of Med. Lab. Science, Sultan Abdurrhman School of Health

Technology Gwadabawa, Sokoto Email : tokanbaduku@yahoo.com Tel: +2348023612828

\begin{abstract}
Background: Cases of diabetes are on the rise in almost every population and without proper management and control the burden of the disease will continue to rise globally. Vitamins and minerals play significant roles in the management of diabetes and studies have shown the hypoglycemic effect of quail's egg.
\end{abstract}

Objectives: The aim of the study was to investigate the effect of Coturnix japonica (Quail) egg on serum glucose and some serum B-vitamins and mineral elements in alloxan induced diabetic rats.

Methods: Rats were rendered diabetic by intravenous injection of alloxan $(80 \mathrm{mg} / \mathrm{kg}$ body weight). Coturnix japonica egg was administered orally at 100, 200 and $400 \mathrm{mg} / \mathrm{kg}$ body weight per day for four weeks to the experimental animal groups. Serum glucose was significantly decreased $(\mathrm{P}<0.05)$ in treated group compared to the non-treated groups. Mean serum concentrations of vitamin B1, B2 and B3 were significantly increased $(\mathrm{P}<0.05)$ in treated group compared to the non-treated groups.

Results: The result also shows a significant increased $(\mathrm{P}<0.05)$ in some antioxidants minerals in treated groups compared to the non-treated groups.

Conclusion: Given the importance of vitamins and minerals in the management of diabetes and metabolic disorders, Coturnix japonica egg supplementation may have important implication in the management of diabetes.

Key words: Coturnix japonica; Diabetes; Mineral elements; Vitamins

\section{INTRODUCTION}

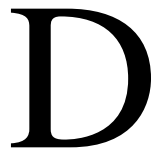
iabetes is a disorder that affects the body's ability to make or use insulin. It is mainly characterized by hyperglycemia that leads to several long term complications. There is an increasing evidence of diabetes in almost every population worldwide and epidemiological studies suggest that without proper prevention, control as well as management measures, the prevalence and the burden of the disease will continue to increase (1). Globally, as of 2010, an estimated 285 million people had diabetes, with type 2 making up about $90 \%$ of the cases $(2,3)$. Its incidence is increasing rapidly, and by 2030 , this number is estimated to almost double (4). Curing diabetes is a difficult task however management measures concentrate on keeping blood glucose to normal levels (5).

The metabolism of several trace elements and B- vitamins has been reported to alter in diabetes and these play a significant role in the pathogenesis of the disease (6). Major role of these B- vitamins and mineral elements is to act as precursors of some co-enzymes and cofactors respectively in several enzymatic pathways of glucose and other nutrients metabolism. Depletion of antioxidant vitamins and minerals may lead to increase oxidative stress, resulting in micro vascular and macro vascular damage leading to essential diabetic specific complications and hypertension $(7,8)$.

Marketed antidiabetic drugs are associated with several negative outcomes. These negative outcomes and possible high cost make search for cheaper and safer hypoglycemic agents an active area of research. It is therefore the objective of the present research to investigate the efficacy of quail egg in the management of diabetes.

\section{MATERIALAND METHODS}

All chemicals and reagents used for this work 


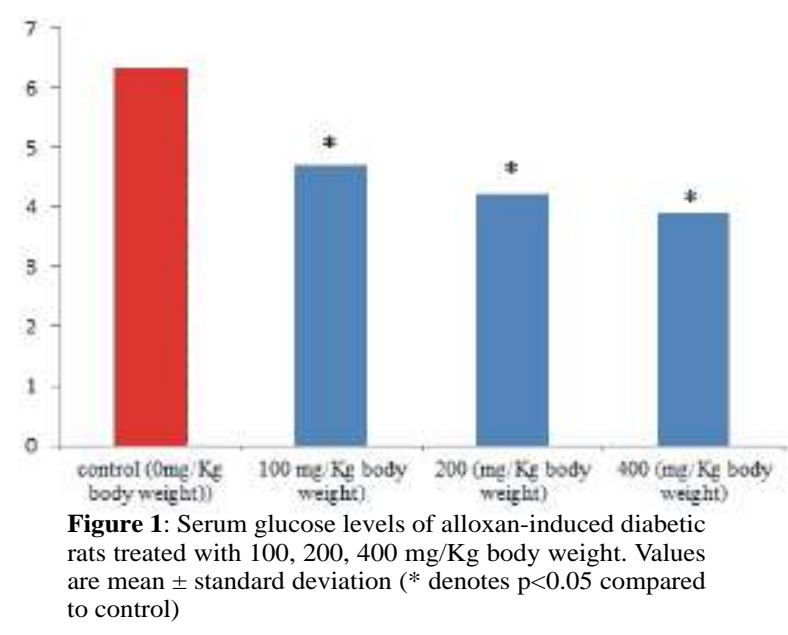

were of analytical grades. Alloxan monohydrate was purchased from Sigma-Aldrich. Assay kits were purchased from Randox laboratory Ltd. United Kingdom.

Experimental Design

Animals: Twenty (20) albino rats of both sexes were used for this study. The animals were purchased from animal house of Usmanu Danfodiyo University, Sokoto and allowed two (2) weeks to acclimatize before the commencement of the experiment. The rats were fed with pelletized grower feed (Vital Feed, Jos Nigeria) and allowed access to water before and during experimental period.

Grouping: The rats were divided into four (4) groups of five (5) rats each as follows: Group I diabetic non- treated (control). Group II: diabetic treated with $100 \mathrm{mg} / \mathrm{kg}$ body weight. Group III: diabetic treated with $200 \mathrm{mg} / \mathrm{kg}$ body weight. Group IV: diabetic treated with $400 \mathrm{mg} / \mathrm{kg}$ body weight.

Induction of Diabetes: All rats except group I were injected with alloxan to induce and

Table 1: B-vitamins and some mineral element composition of Coturnix japonica egg

\begin{tabular}{ll}
\hline \multicolumn{1}{c}{ Parameter } & Concentration \\
\hline Vit. B1 $(\mathrm{mg} / \mathrm{dl})$ & $0.193 \pm 0.001$ \\
VIt. B2 $(\mathrm{mg} / \mathrm{dl})$ & $1.945 \pm 0.001$ \\
Vit. B3 $(\mathrm{mg} / \mathrm{dl})$ & $0.060 \pm 0.010$ \\
Copper $(\mathrm{Cu})(\mathrm{ppm})$ & $0.006 \pm 0.000$ \\
Zinc $(\mathrm{Zn})(\mathrm{ppm})$ & $0.190 \pm 0.001$ \\
Iron $(\mathrm{Fe})(\mathrm{ppm})$ & $0.051 \pm 0.002$ \\
Magnesium $(\mathrm{Mg})(\mathrm{ppm})$ & $0.092 \pm 0.001$ \\
Manganese $(\mathrm{Mn})(\mathrm{ppm})$ & $0.011 \pm 0.001$ \\
Chromium $(\mathrm{Cr})(\mathrm{ppm})$ & $0.101 \pm 0.001$
\end{tabular}

Values are mean \pm standard deviation accelerate the progression of diabetes. The animals were injected with alloxan $150 \mathrm{mg} / \mathrm{kg}$ body weight daily for 3 days (9). Glucose level was measured with Glucometer. Rats with fasting blood glucose level > 7.0mmol/1 $(126 \mathrm{mg} / \mathrm{dl})$ were included in the study.

Coturnix japonica (Quail) egg: Coturnix japonica (Quail) eggs were purchased from Sokoto central market. The eggs were identified by animal scientist, department of animal science, Usmanu Danfodiyo University, Sokoto.

Treatment: The treatment commenced after the third day of alloxan induction. The treated groups in all cases were administered the egg (whole egg except the shell) orally at $100 \mathrm{mg} / \mathrm{kg}$, $200 \mathrm{mg} / \mathrm{kg}$ and $400 \mathrm{mg} / \mathrm{kg}$ body weight per day respectively, for four weeks. The rats in all groups were maintained on poultry growers mash and tap water throughout the experimental period.

Blood and Serum Collection: After 24 hours of last treatment, the rats were decapitated with the aid of Razor blade and blood specimens collected into labeled centrifuge tube and allowed to clot for 5 mins. The blood specimen was then centrifuged in a Bench Top Centrifuge (Model No: 8000) at 4000rpm for 5mins. The serum were separated and kept in labeled sample bottles at $4^{\circ} \mathrm{C}$ until required for analysis. Biochemical Analysis: Serum glucose was estimated using the glucose oxidase method (10). Chromium, Manganese, Magnesium, Iron, Copper and Zinc were estimated using UNICAM 969 Atomic Absorption Spectrophotometer (11). Vitamin B1, B2 and B3 were estimated using the method described by Okwu \& Josaih (12).

Statistical analysis

The results were expressed as mean \pm standard deviation for 5 rats in each group. The biochemical parameters were also analyzed statistically using one way analysis of variance (ANOVA), followed by Dunnet multiple comparison test. $\mathrm{P}<0.05$ was considered statistically Significant.

Results and Discussion

Mineral Elements and B-Vitamins Composition of Coturnix japonica egg 
Table 2: Serum mineral elements of alloxan-induced diabeti c rats orally administered with Coturnix japonica egg

\begin{tabular}{lllllll}
\hline $\begin{array}{l}\text { Dose } \\
(\mathbf{m g} / \mathbf{k g ~ B W})\end{array}$ & $\begin{array}{l}\mathbf{M g} \\
(\mathbf{p p m})\end{array}$ & $\begin{array}{l}\mathbf{M n} \\
(\mathbf{p p m})\end{array}$ & $\begin{array}{l}\mathbf{C u} \\
(\mathbf{p p m})\end{array}$ & $\begin{array}{l}\mathbf{C r} \\
(\mathbf{p p m})\end{array}$ & $\begin{array}{l}\mathbf{Z n} \\
(\mathbf{p p m})\end{array}$ & $\begin{array}{l}\mathbf{F e} \\
(\mathbf{p p m})\end{array}$ \\
\hline control & $12.86 \pm 3.03$ & $0.21 \pm 0.05$ & $0.08 \pm 0.07$ & $0.03 \pm 0.01$ & $0.51 \pm 0.37$ & $0.37 \pm 0.11$ \\
100 & $14.29 \pm 0.00^{\mathrm{a}}$ & $0.09 \pm 0.05$ & $0.11 \pm 0.04^{\mathrm{a}}$ & $0.05 \pm 0.03$ & $0.26 \pm 0.07$ & $0.27 \pm 0.05$ \\
& & & & & & \\
200 & $16.43 \pm 0.00^{\mathrm{a}}$ & $0.09 \pm 0.05$ & $0.10 \pm 0.09^{\mathrm{a}}$ & $0.08 \pm 0.06^{\mathrm{a}}$ & $0.43 \pm 0.13$ & $0.47 \pm 0.11^{\mathrm{a}}$ \\
400 & $13.22 \pm 1.52^{\mathrm{a}}$ & $0.07 \pm 0.07$ & $0.07 \pm 0.02$ & $0.08 \pm 0.04^{\mathrm{a}}$ & $0.48 \pm 0.11$ & $0.48 \pm 0.11^{\mathrm{a}}$
\end{tabular}

Values are mean \pm standard deviation. Values bearing asterisk differ significa ntly $(P<0.05)$ compared to control.

The results of the mineral elements and Bvitamins composition of Coturnix japonica egg is presented in table 1 . Among the three Bvitamins analyzed, vitamin B2 has the highest concentration $(1.945 \pm 0.001 \mathrm{mg} / \mathrm{dl})$ compared to vitamin B1 $(0.193 \pm 0.001 \mathrm{mg} / \mathrm{dl})$ and vitamin B3 $(0.060 \pm 0.010 \mathrm{mg} / \mathrm{dl})$. The levels of mineral elements were similar, however $\mathrm{Cr}$ and $\mathrm{Zn}$ levels were found to be higher.

Effect of Coturnix japonica egg Supplementation on some Serum mineral element levels of Alloxan-induced diabetic Rats Results of the serum mineral elements of alloxan-induced diabetic rats treated with 100 , 200 or $400 \mathrm{mg} / \mathrm{Kg}$ body weight Coturnix japonica egg is presented in table 2. Some of these elements have important implication in metabolic pathways. Chromium is required for maintenance of normal glucose metabolism and deficiency may lead to impairment in glucose tolerance (13). Little or no chromium containing enzymes exist, however studies have

Table 3: Serum vitamin B1, B2, B3 levels in alloxan-induced diabetic rats orally administered with Coturnix japonica egg

\begin{tabular}{llll}
\hline $\begin{array}{l}\text { Dose } \\
(\mathbf{m g} / \mathbf{k g ~ b w})\end{array}$ & $\begin{array}{l}\text { Vit. B1 } \\
(\mathbf{m g} / \mathbf{d l})\end{array}$ & $\begin{array}{l}\text { Vit. B2 } \\
(\mathbf{m g} / \mathbf{d l})\end{array}$ & $\begin{array}{l}\text { Vit. B3 } \\
(\mathbf{m g} / \mathbf{d l})\end{array}$ \\
\hline control & $0.240 \pm 0.030$ & $0.752 \pm 0.044$ & $0.210 \pm 0.150$ \\
100 & $0.290 \pm 0.010$ & $0.885 \pm 0.021^{\mathrm{a}}$ & $0.560 \pm 0.060^{\mathrm{a}}$ \\
200 & $0.300 \pm 0.090^{\mathrm{a}}$ & $0.889 \pm 0.029^{\mathrm{a}}$ & $0.640 \pm 0.000^{\mathrm{a}}$ \\
400 & $0.290 \pm 0.280$ & $0.980 \pm 0.004^{\mathrm{a}}$ & $0.680 \pm 0.040^{\mathrm{a}}$ \\
\hline
\end{tabular}

Values are mean \pm standard deviation. Values bearing asterisk differ significantly $(P<0.05)$ compared to control. shown chromium to act by enhancing insulin action (7). Magnesium and Zinc function as essential cofactors of several enzymes of energy metabolism (14). Since decreased levels of these elements have been shown in diabetic patients, Coturnix japonica egg supplementation may increase their levels thereby increasing the chances of managing the disease.

Effect of Coturnix japonica egg Supplementation on Some serum B-vitamins levels of Alloxan-induced diabetic Rats

Vitamins are important components of the diet, playing significant roles in the management of several metabolic disorders. Effects of vitamins supplementation in the management of diabetes have been studied in several clinical trials. For example, vitamin B3 has been shown to protect the $\beta$-cells of the pancreas and act as antioxidant (7). The significant increase in the levels of vitamins in rats treated with Coturnix japonica egg could be due to increase bioavailability of these micronutrients that are important composition of the egg. These findings are in agreement with the findings of (15) who reported increase levels of antioxidant vitamins in rats supplemented with nutraceuticals.

Effect of Coturnix japonica egg 
Supplementation on Serum Glucose levels of Alloxan-induced diabetic Rats

Blood Glucose levels in diabetic untreated and diabetic treated with 100, 200 and $400 \mathrm{mg} / \mathrm{Kg}$ body weight Coturnix japonica egg is presented in figure 1. Serum glucose levels in diabeticuntreated was $6.33 \pm 0.74$ while diabetic treated with 100,200 or $400 \mathrm{mg} / \mathrm{Kg}$ body weight was $4.7 \pm 0.85,4.23 \pm 0.78$ and $3.9 \pm 0.58 \mathrm{mmol} / \mathrm{L}$ respectively. Thus treatment with Coturnix japonica egg is associated with significant decrease in serum glucose levels. The significant decrease in serum glucose levels could be due to observed presence of vitamins and mineral elements in Coturnix japonica egg leading to their increase bioavailability. Several of these vitamins and minerals act as coenzyme or cofactors of enzymes involve in energy metabolism (7).

\section{CONCLUSION}

The current study demonstrates the efficacy of Coturnix japonica egg in the management of diabetes in alloxan-induced diabetic rats. This suggests that consumption of Coturnix japonica egg may have important implication in the management of diabetes in humans. However, further studies are required to elucidate the safety as well as the detailed possible mechanism of action.

\section{REFERENCES}

1. Alberti KG, Zimmet P \& Shaw J (2007). International Diabetes Federation: A consensus on type 2 diabetes Prevention. Diabetes Medicine, 24(5):451-463.ss

2. Showback A (2010). Greenspan's basic \& clinical endocrinology (9th ed.) edited by David G. New York: McGraw-Hill Medical. Pp Chapter 17.

3. Shaw JE, Sicree RA \& Zimmet PZ (2010). Global estimates of the prevalence of diabetes for 2010 and 2030. Diabetic Research in Clinical Practice. 87: 4-14.

4. Sattar N, Preiss D, Murray H M, Welsh P, Buckley BM, De Craen AJ, Seshasai SR, McMurray JJ, \& Freeman DJ (2010). "Statins and risk of incident diabetes: a collaborative meta-analysis of randomised statin trials". The Lancet, 375 (9716):
735-42.

5. World Health Organization (WHO) (2006). Definition and Diagnosis of Diabetes mellitus and intermediate hyperglycemia: Report of a WHO/IDF consultation Geneva, p21.

6. Coyne T (2005). Antioxidant. American Journal Clinical Nutrition, 82:3685-3698.

7. O'Connell BS (2001). Select vitamins and minerals in the management of diabetes. Diabetes spectrum, 14(3):133-148.

8. Ugwuja EI, Nwibo AN, Ezenkwa US, Oshim AN, Nnabu RC, Ogiji ED, Ogbanshi M (2014). Effects of diabetes complications and glycemic control on some mineral elements in Nigerian patients with diabetes. Journal of Diabetology, February 2014, 1:1.

9. Kameswara BR, Kesavulu MM, Giri R \& Rao CA (1999). Antidiabetic and hypolipodaemic effect of Momordica cymbaria hook fruit powder in alloxan diabetic rats. Journal of Ethnopharmacology, 67:103-109.

10. Trinder $P$ (1969): Annals of Clinical Biochemistry, 6:24 quoted in Cheesbrough M (1992). Medical Laboratory Manual for Tropical Countries, Volume 1 (second edition), Cambridge 527-545.

11. Greeg LM (1989). Water analysis handbook. H. A. C. H. Company USA Pp: 33-39.

12. Okwu DE \& Josaih C (2006). Evaluation of the chemical composition of two Nigerian medicinal plants. African Journal of Biotechnology, 5 (4): 357-361.

13 Anderson RA (1998). Chromium, glucose intolerance and diabetes. Journal of American College of Nutrition, 17:548-555.

14. De Valk H (1999). Magnesium in diabetes mellitus. Netherlands Journal of Medicine, 54:139-146.

15. Saidu Y, Bilbis LS, Muhammad SA \& Nasiru MK (2012). Serum lipid profile and antioxidants status of salt-induced hypertensive rats with an antioxidant rich nutraceutical. Cameroon Journal of Experimental Biology, 8(1):47-54. 